\title{
THE EFFECT OF DIAMOND DUST ALONE AND MIXED WITH QUARTZ ON THE LUNGS OF RATS
}

\author{
BY
}

\author{
E. J. KING, M. YOGANATHAN, and G. NAGELSCHMIDT \\ From the Postgraduate Medical School, London, and the Safety in Mines Research Establishment, Sheffield
}

(RECEIVED FOR PUBLICATION DECEMBER 7, 1957)

Diamond, the hardest of all minerals, was classed as an inert material, similar to anthracite and corundum, by Gardner (1938) on the basis of intravenous injection experiments in rabbits. By intraperitoneal injection into mice Bovet (1952) produced collagenous nodules in places where much diamond dust was accumulated. But it took six months to one year for such nodules to form as against a few weeks for quartz of similar size.

Schiller (1955) injected diamond dust intraperitoneally into mice, alone and combined with silicic acid in the form of " aerosil ". The diamond dust produced only very slight fibrosis of the tissues, but laminated fibrous granulomata were formed after 60 days in the animals injected with silicic acid plus the diamond dust, on which Schiller supposed the silicic acid had been adsorbed.

Pure coal dust injected intratracheally into the lungs of different animals produces no other pathological result than the formation of a very few reticulin fibres within focal accumulations of the dust (Belt and King, 1945). Small amounts of free silica dusts (quartz, tridymite) are partly or wholly eliminated from the lungs into the lymph nodes and therefore produce little or no fibrosis in the lungs, but when these small amounts of free silica dusts are combined with large quantities of coal dust they produce more fibrosis in the lungs than the apparent sum of the two of them taken separately (Ray, King, and Harrison, 1951; Attygalle, King, Harrison, and Nagelschmidt, 1956). The same result was obtained with graphite, and we have now repeated the experiment with diamond dust alone and admixed with small amounts of quartz.

\section{Experimental}

Five experiments were set up as follows:-

(1) $100 \mathrm{mg}$. diamond dust

(2) $2 \mathrm{mg}$. quartz dust

(3) $5 \mathrm{mg}$. quartz dust

(4) $100 \mathrm{mg}$. diamond dust $+2 \mathrm{mg}$. quartz

(5) $100 \mathrm{mg}$. diamond dust $+5 \mathrm{mg}$. quartz dust.
All the substances were injected intratracheally.

The diamond dust was purchased as "diadust" (pure diamond powder-grade PMO/2).

The quartz dust was prepared from Madagascar quartz crystals, containing $99.6 \% \mathrm{SiO}_{2}$. The fraction $0 \cdot 5-2 \mu$ was prepared by repeated sedimentation in water after grinding the material in a mechanically driven agate mortar. The silica solubility of this fraction was $13.5 \mathrm{mg}$. $\mathrm{SiO}_{2}$ per $100 \mathrm{ml}$. in Ringer solution.

The size distributions of the diamond and quartz dusts are given in Table 1.

TABLE 1

PARTICLE SIZE DISTRIBUTION OF DIAMOND AND QUARTZ DUST

\begin{tabular}{|c|c|c|c|c|}
\hline Size $(\mu)$ & \multicolumn{2}{|c|}{ Diamond (\%) } & \multicolumn{2}{|c|}{ Quartz ( $\%)$} \\
\hline & By No. & By Mass & By No. & By Mass \\
\hline $\begin{array}{l}0.08-0.11 \\
0.12-0.16 \\
0.17-0.23 \\
0.24-0.32 \\
0.33-0.45 \\
0.46-0.64 \\
0.65-0.9 \\
1.0-1.3 \\
1.4-1.8 \\
1.9-2.6 \\
2.7-3.6\end{array}$ & $\begin{array}{r}0.4 \\
7.1 \\
14.1 \\
22.8 \\
23.5 \\
21.5 \\
7.6 \\
2.5 \\
0.2\end{array}$ & $\begin{array}{r}0.2 \\
0.8 \\
3.4 \\
10.5 \\
26.9 \\
27.0 \\
25.0 \\
6.2\end{array}$ & \begin{tabular}{r|}
0.8 \\
$3 \cdot 4$ \\
$4 \cdot 7$ \\
3.8 \\
$3 \cdot 4$ \\
2.4 \\
19.8 \\
$31 \cdot 7$ \\
$24 \cdot 1$ \\
5.7 \\
0.2
\end{tabular} & $\begin{array}{r}0.1 \\
0.2 \\
4 \cdot 5 \\
19.9 \\
43 \cdot 1 \\
28 \cdot 7 \\
3.5\end{array}$ \\
\hline $\begin{array}{l}\text { Specific surface } \\
\left(\mathrm{m}^{2} \text { per } \mathrm{g} .\right) \\
\text { Mean volume-surface } \\
\text { diameter }\left(\mathrm{D}_{\mathrm{vs}}\right)\end{array}$ & & & & $\begin{array}{l}0 \\
46\end{array}$ \\
\hline
\end{tabular}

The dust suspensions were prepared for injection by dispersing the required amount of the dust, or the dust mixture, in physiological saline solution in a glass tissue grinder. The suspension was sterilized by autoclaving, and $5 \%$ of fresh sterile rat serum added to it. The dust suspensions were prepared on the day of injection, and were kept continually agitated on a mechanical shaker until used.

The rats used, seven males for each experiment, were of the black and white hooded variety supplied by the Medical Research Council. Their average weight was $225 \mathrm{~g}$.

The injection technique was that of Belt and King (1945) as modified by Attygalle et al. (1956), to allow introduction of the dust suspension through a long blunt 92 
TABLE 2

PATHOLOGICAL CHANGES PRODUCED IN RAT LUNGS BY DIAMOND AND QUARTZ DUSTS

\begin{tabular}{|c|c|c|c|c|c|c|c|c|c|c|}
\hline \multirow{2}{*}{$\begin{array}{l}\text { Days of } \\
\text { Survival }\end{array}$} & \multicolumn{2}{|c|}{ Diamond (100 mg.) } & \multicolumn{2}{|c|}{ Quartz (2 mg.) } & \multicolumn{2}{|c|}{$\begin{array}{c}\text { Diamond (100 mg.) } \\
+ \\
\text { Quartz (2 mg.) }\end{array}$} & \multicolumn{2}{|c|}{ Quartz (5 mg.) } & \multicolumn{2}{|c|}{$\begin{array}{c}\text { Diamond (100 mg.) } \\
+ \\
\text { Quartz (5 mg.) }\end{array}$} \\
\hline & $\begin{array}{l}\text { Mode of } \\
\text { Death }\end{array}$ & $\begin{array}{l}\text { Grade of } \\
\text { Fibrosis }\end{array}$ & $\begin{array}{c}\text { Mode of } \\
\text { Death }\end{array}$ & $\begin{array}{l}\text { Grade of } \\
\text { Fibrosis }\end{array}$ & $\begin{array}{l}\text { Mode of } \\
\text { Death }\end{array}$ & $\begin{array}{l}\text { Grade of } \\
\text { Fibrosis }\end{array}$ & $\underset{\text { Death }}{\text { Mode of }}$ & $\begin{array}{l}\text { Grade of } \\
\text { Fibrosis }\end{array}$ & $\begin{array}{l}\text { Mode of } \\
\text { Death }\end{array}$ & $\begin{array}{l}\text { Grade of } \\
\text { Fibrosis }\end{array}$ \\
\hline 100 & Died & $\begin{array}{l}0 \\
0\end{array}$ & Died & & Died & 1 & & & Died & 1 \\
\hline 200 & Killed & 0 & Killed & 1 & Killed & 1 & Killed & 1 & Killed & 1 \\
\hline 300 & ," & $\begin{array}{l}\mathbf{0} \\
\mathbf{0}\end{array}$ & ," & 1 & ," & $\begin{array}{l}1 \\
1\end{array}$ & ”, & $\begin{array}{l}1 \\
2\end{array}$ & ," & $2 \max$. \\
\hline 400 & ," & $\mathbf{0}$ & ", & 1 & ", & $\begin{array}{l}1 \\
2\end{array}$ & ,", & $\begin{array}{l}2 \\
2\end{array}$ & , & $2 \max$. \\
\hline & , & $\mathbf{0}$ & , & 1 & $"$ & 2 & ", & $\begin{array}{l}2 \\
2\end{array}$ & $"$ & \\
\hline
\end{tabular}

Max. = maximal within the stated grade of fibrosis.

needle inserted through the mouth and down to the bifurcation of the trachea.

The duration of the experiments was 400 days. A few animals died, and the rest were killed at intervals (Table 2).

The histological and pathological procedures were as described by Belt and King (1945) and as detailed in the other communications from this laboratory already referred to.

The pathological results of the injections of dusts were assessed histologically, in terms of degrees of fibrosis as defined by Belt and King (1945), i.e., grade 1 fibrosis, in which, with ordinary nuclear stains, the lesions appear cellular, while a loose network of reticulin is seen with silver impregnation, no collagen being demonstrable. In grade 2 fibrosis lesions are cellular with the reticulin fibres becoming thicker and arranged in a compact manner; there may or may not be collagen. In grade 3 fibrosis lesions are slightly cellular and composed mainly of collagen fibres. Two further grades are recognized, namely, grade 4 fibrosis in which the lesions are completely acellular and wholly collagenous, and grade 5 fibrosis, in which lesions are acellular, collagenous, and confluent, but these were not attained in this experiment.

\section{Results}

The diamond dust alone gave rise to no fibrosis even after 400 days. With quartz alone, $2 \mathrm{mg}$. produced a few scattered lesions of grade 1 fibrosis by 200 days, with no increase at 400 days, while $5 \mathrm{mg}$. produced a few scattered nodules of grade 2 fibrosis by 300 days, with no increase at 400 days.

Diamond dust combined with $2 \%$ of quartz dust (100 mg. diamond $+2 \mathrm{mg}$. quartz) caused numerous lesions of grade 1 fibrosis at 200 days, which progressed to grade 2 at 400 days. With $5 \%$ of quartz combined with diamond the lesions appeared to be more numerous, and were slightly more fibrotic, i.e., grade 1 at 200 days and grade 2 maximum and grade 3 at 400 days. It seems, therefore, that the combined effect of diamond dust and varying amounts of quartz is to produce more pathological response than either of them produces alone, and that, as with coal, the effects of the combined dusts are greater than the apparent sums of each of them taken separately. Photomicrographs of representative sections of the lungs are reproduced in Figs. 1-5.

\section{Discussion}

Attygalle et al. (1956) found that $1 \mathrm{mg}$. tridymite was almost entirely cleared from the lungs, where no fibrosis was found, but that it gave rise to grade 1 maximum fibrosis of the lymph nodes. The $2 \mathrm{mg}$. and $5 \mathrm{mg}$. of quartz used in the present experiments were not completely cleared from the lungs, and some scattered foci of fibrosis were found, particularly with the $5 \mathrm{mg}$. As in the case of coal, it appeared that with diamond dust present in large amounts in the lung there is less movement of small amounts of quartz particles to the lymph nodes than there is in the absence of the diamond dust. Nussbaum (1956) has also advanced the view that innocuous dust in large concentrations may enhance the effect of small amounts of injurious dust by retarding their elimination from the lung.

An injection of $100 \mathrm{mg}$. of dust into a rat will result in permanent retention of about $50 \mathrm{mg}$. (Nagelschmidt, Nelson, King, Attygalle, and Yoganathan, 1957). Human lungs of $200 \mathrm{~g}$. dry weight are approximately 300 times heavier than rat lungs of average dry weight of $0.7 \mathrm{~g}$., so that the dose applied would correspond to finding in a human lung $15 \mathrm{~g}$. of total dust with 0.3 to $0.75 \mathrm{~g}$. of quartz. Such amounts are found in lungs of pathological grade 2 (reticulation) in South Wales coal workers (King, Maguire, and Nagelschmidt, 1956), or in lungs which show radiological stage 1 of simple pneumoconiosis, according to unpublished data. These are comparatively early stages of disease not usually associated with any disability.

It is known that in man dusts with a proportion of quartz of the order of $20 \%$ or more cause silicosis. Coal-mine dusts contain on an average only 2 to 

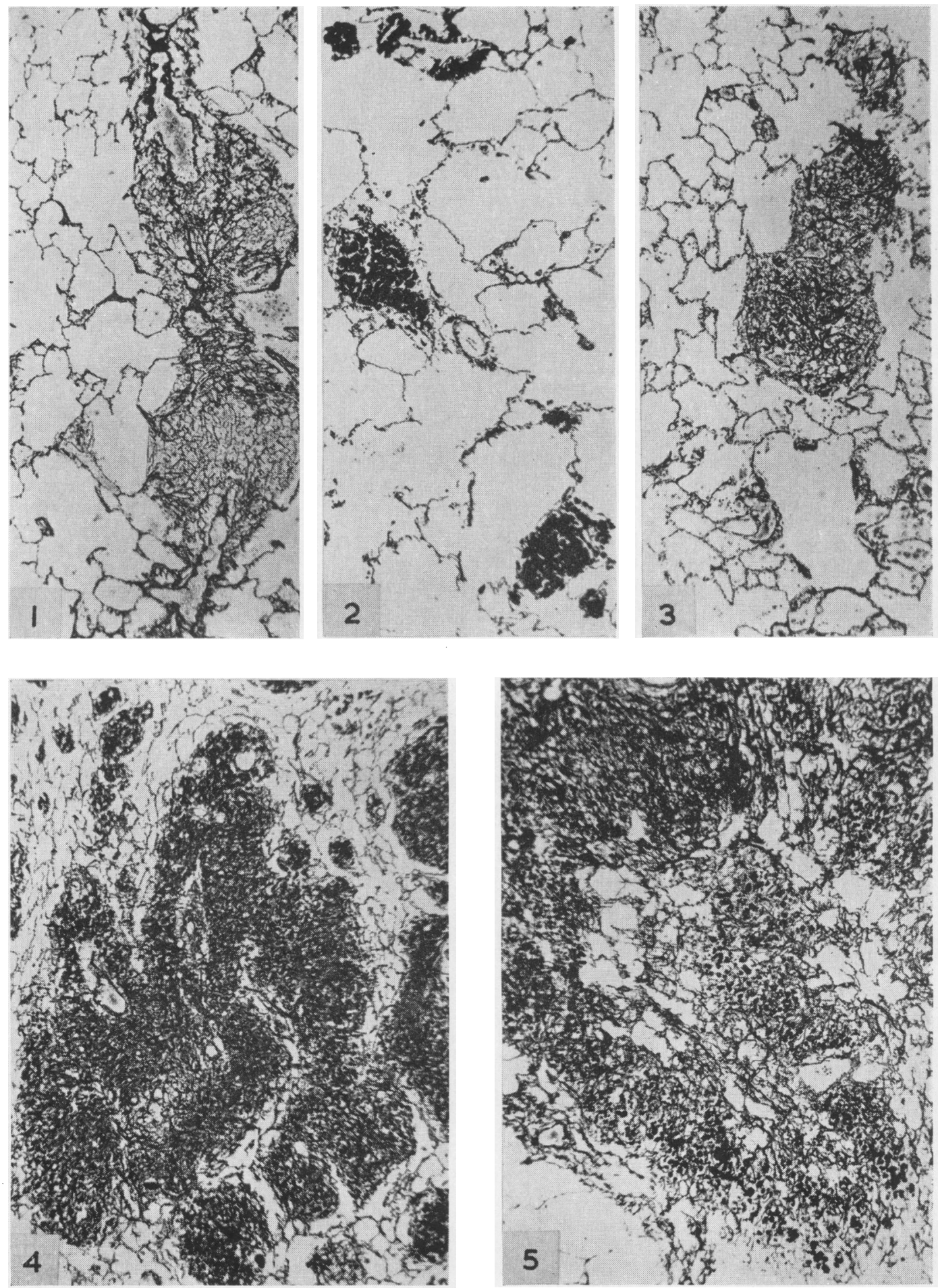

Figs. 1-5.-Rat lungs 400 days after the intratracheal injection of quartz dust, diamond dust, and diamond mixed with quartz dust. Silver impregnation $\times 90$

Fig. 1.-Quartz dust, $2 \mathrm{mg}$., peribronchial nodules of reticulin fibres. Grade 1 fibrosis.

FIG. 2.-Diamond dust, $100 \mathrm{mg}$. Small compact foci densely packed with dust; no increase of reticulin.

Fig. 3.-Quartz dust, $5 \mathrm{mg}$. Small compact nodule composed of thick strands of reticulin and some collagen fibres. Grade 2 fibrosis.

Fig. 4.-Diamond dust, $100 \mathrm{mg}$., plus quartz dust, 2 mg. Compact lesions containing much dust and composed of thick reticulin and collagen fibres. Grade 2 fibrosis.

Fig. 5.-Diamond dust, $100 \mathrm{mg} .$, plus quartz dust, $5 \mathrm{mg}$. Lesions containing much dust and composed of thick strands of reticulin and collagen fibres. Grade 2 fibrosis maximum. 
$4 \%$ of quartz, and the aetiological significance of quartz in such mixed dusts is not well established. The experiments described above and similar previous experiments suggest that fibrosis is slightly more advanced when 2 or $5 \%$ of quartz is injected with large doses of coal, graphite, or diamond, but it is not certain that similar results would be given by dust inhalation; further experiments to establish this point are in progress.

\section{Summary}

Diamond dust (100 mg.; $99 \%$ under $2 \mu$ ) caused no fibrosis in rats' lungs in $\mathbf{4 0 0}$ days when introduced by the intratracheal injection technique. Small amounts of quartz (2 and $5 \mathrm{mg}$.; $95 \%$ under $2 \mu$ ) produced only a few scattered lesions of grades 1 and 2 fibrosis. Diamond dust (100 mg.) combined with quartz ( 2 and $5 \mathrm{mg}$.) produced many more lesions which were somewhat more fibrosed (grade 2, and 2 maximum, and 3). The results are discussed in their possible relation to coal-miner's pneumoconiosis.

We are grateful to the Medical Research Council and to the National Coal Board for grants to defray the expenses of this investigation, and to Mr. B. S. C. Hollands for skilled technical assistance, and the Ministry of Power for permission to publish this paper.

\section{REFERENCES}

Attygalle, D., King, E. J., Harrison, C. V., and Nagelschmidt, G. (1956). Brit. J. industr. Med., 13, 41.

Belt, T. H., and King, E. J. (1945)., Spec. Rep. Ser. med. Res. Coun., (Lond.), No. 250.

Bovet, P. (1952). Schweiz. Z. allg. Path., 15, 548.

Gardner, L. U. (1938). Industr. Med. Surg., 7, 738

King, E. J., Maguire, B. A., and Nagelschmidt (1956). Brit. J. industr. Med. $13,9$.

Nagelschmidt, G., Nelson, E. S., King, E. J., Attygalle, D., and Yoganathan, M. (1957). Arch. industr. Hith, 16, 188.

Nussbaum, R. (1956). Arch. Mal. prof., 17, 350.

Ray, S. C., King, E. J., and Harrison, C. V. (1951). Brit. J. industr. Med. $8,68$.

Schiller, E. (1955). Arch. Gewerbepath. Gewerbehyg., 14, 1

\section{THE JANUARY (1958) ISSUE}

The January (1958) issue contains the following papers:-

The Treatment of Experimental Silicosis with Compound 48/80. By J. Marks, Dinah M. James, and T. G. Morris. Immunological Factors in the Pathogenesis of the Hyaline Tissue of Silicosis. By E. C. Vigliani and B. Pernis.

Toxic Properties of Some Dialkyl and Trialkyl Tin Salts. By J. M. Barnes and H. B. Stoner.

Pulmonary Disease amongst Sisal Workers. By Hugh Stott.

Heat Stress in Non-ferrous Foundries. By D. Turner.

Some Clinical and Administrative Aspects of Occupational Health. By Kenneth P. Duncan.

Dermatoses in the Manufacture of Glass Fibre. By William B. McKenna, J. F. Ferguson Smith, and Donald A. Maclean.

Absence from Work in Relation to Wage Level and Family Responsibilities. R. D. Shepherd and J. Walker.

Studies on the Risks Associated with the Use of Parathion-impregnated Gauze Strips in Fly Control. By Jon Glömme and $\AA$. Swensson.

Miscellanea:

Health, Welfare, and Safety in New Zealand. By T. O. Garland.

Obituary:

Ludwig Teleky.

E. L. Collis.

Book Reviews.

A number of copies are still available and may be obtained from the Publishing Manager, British Medical Association, Tavistock Square, W.C.1, price 17s. 6d. 